Article

\title{
Restaurant's Multidimensional Evaluation Concerning Food Quality, Service, and Sustainable Practices: A Cross-National Case Study of Poland and Lithuania
}

\author{
Joanna Trafialek ${ }^{1, *(\mathbb{D})}$, Ewa Czarniecka-Skubina ${ }^{1} \mathbb{D}$, Jurgita Kulaitiené ${ }^{2} \mathbb{D}$ and \\ Nijolè Vaitkevičiené ${ }^{2}(\mathbb{D}$ \\ 1 Department of Food Gastronomy and Food Hygiene, Institute of Human Nutrition Sciences, \\ Warsaw University of Life Sciences (WULS), 02-787 Warszawa, Poland; ewa_czarniecka_skubina@sggw.pl \\ 2 Institute of Agricultural and Food Science, Vytautas Magnus University Agriculture Academy (VMU-AA), \\ LT-50240 Kaunas, Lithuania; jurgita.kulaitiene@vdu.lt (J.K.); nijole.vaitkeviciene@vdu.lt (N.V.) \\ * Correspondence: joanna_trafialek@sggw.pl; Tel.: +48-22-5937082
}

Received: 20 November 2019; Accepted: 24 December 2019; Published: 27 December 2019

\begin{abstract}
The purpose of this study was to identify and analyze consumer choices and evaluate the restaurant service quality, including quality of meals and services, and sustainability practices in restaurants in Warsaw and Kaunas. Our research was conducted using a sample of 1200 adult Poles and Lithuanians. Polish and Lithuanian consumers used catering services with varying frequencies. Different elements influenced their choice of restaurant. However, the common feature was the quality of meals, which in Lithuania was compared only with the price of meals, and with other elements in Poland. In the context of restaurant's sustainable practices, it has been revealed that surveyed consumers had only partially fit into the contemporary consumption trends. In both countries, consumers have appreciated the use of reusable cutlery and crockery, as well as local and seasonal ingredients, while they did not pay attention to sustainable restaurant practices, such as the use of alternative sources of protein, environmentally friendly forms of energy, and reducing waste and minimization of food losses. The use of cluster analysis and principal component analysis (PCA) allowed a comprehensive assessment of consumer opinions on restaurants in terms of meal quality and service as well as sustainable practices. Restaurateurs should monitor the satisfaction of their customers and recognize the changing needs and habits of consumers.
\end{abstract}

Keywords: restaurant; consumer; food quality; service quality; sustainable practices; Poland; Lithuania

\section{Background}

The approach of consumers to food and their eating behavior is constantly changing. An increasingly longer working day, as well as the demographic (an increase in the number of older people and small households) and economic changes (increasing development of states, enrichment of societies) contribute to the growing interest and development of catering services. These, in turn, are continuously adapting to the changing requirements of customers, as well as to different types of customers [1,2].

Diet-related diseases are becoming increasingly common. Therefore, the nutritional awareness of consumers, who are showing an increasing concern for health, is growing and being manifested in regular and rational nutrition, including dietetical aspects, as well as eating meals of appropriate quality, e.g., organic, vegetarian, or allergen-free food. Moreover, in view of the need to ensure a sustainable development of society, there is a need to support and promote the consumption of healthy and environmentally friendly foods [3]. Organic and sustainable food products are often bought not only for environmental motives, but also for other reasons, such as health or taste [4-6]. Awareness 
of the owners of catering establishments and legislative bodies are also changing. This happened in the case of the obligation to provide information on allergens which is also in relation to the meals in gastronomy [7]. A few years ago, e.g., 10\% of meals sold in Ireland catering establishments as "gluten free" contained some gluten as stated by some authors [8,9]. As illustrated by Müller et al. [3], some large caterers offered a range of meals in accordance with current nutritional recommendations or environmentally friendly dishes. Reducing the portion of food intake is a promising strategy in reducing energy intake by consumers and tackling obesity and it is also associated with reducing food waste [10-12].

Food scandals have caused consumers to question the quality of food products. Scientific literature provides empirical support that perceived food quality as the most critical factor in customers' choice of restaurants [13,14]. On the other hand, some authors [15] suggested that food quality is a key predictor of customers' dining satisfaction. Satisfaction has been conceptualized in many ways. Food satisfaction is a feeling developed based on the consumed food and appears before as well as during and after intake. Edwards [16] stated that when examining eating out, it is important to consider not only the food or meal, but also the customer and the situation under which the consumption will take place.

\section{Introduction}

Multiple factors contribute to food satisfaction when consumers eat out. Among such factors are satiation, sensory experience, and food quality, knowledge about the food including nutritional value and origin, healthiness, visual attractiveness, freshness, price/value, promotion, social company, and variety/innovations [17-27]. The food quality is the most important factor in determining customer satisfaction and behavioral intention [28-30]. There are a number of other restaurant service attributes that affect customer satisfaction: food presentation, tasty food, spatial seating arrangement, fascinating interior design, pleasing background music and mood, reliable service, and service responsiveness. Many of them are important in contributing to the satisfaction of a restaurant's meals [31,32]. Some authors suggested [33] that physical environment is important in increasing customer satisfaction and influencing restaurant selection by consumers. The numerous environmental factors affecting food consumption include odor, color, physical surroundings, and the effect of lighting [34,35]. The importance of each factor can vary between persons. The consumer, currently choosing a catering establishment, pays attention to many elements of food service that have not been taken into account previously.

More attention is being paid to consumers' awareness and their public self-consciousness in the context of the satisfaction resulting from eating out $[15,36]$. For example, sustainable consumption, involving a reasonable use of consumer goods in an attempt to balance the global ecosystem with the future generations and the planet's survival in mind. In the last decade, launching sustainable production and consumption has become a major priority of the EU. Food service providers have started recognizing the important role they play in managing the negative environmental impacts associated with their operations [37]. There are several negative environmental impacts, such as excessive energy consumption associated with carbon footprint build-up [38], 30\% of global greenhouse gases, emissions [17,39], and contribution to food waste [40]. Along with this interest, both of consumers and restaurant owners, new trends are developing, such as trends in organic food consumption, environmental and sustainable practices, green consumerism and green restaurants, promoting local foods, and organic foods and low-carbon foods [25,41,42]. The growing interest of the population in a healthy life is a constant of modern society. The culinary habits are essential elements in this respect. Different studies [43-45] suggests that contemporary catering consumers have become more demanding in terms of their food choices at restaurants. According to them, consumers focus more on the food origin, what ingredients it contains and what impacts it imposes on customer health, the well-being of local communities, and the environment, and select food based on its environmental credentials and ethical values.

However, there is only a small amount of data on how customers evaluate sustainable practices in the restaurant, in which they eat meals. The previous research on pro-environmental consumer choice in food service provision has predominantly documented consumer intensions rather than captured the actual consumer behavioral patterns [46]. Environmental factors have also been investigated, 
looking at the benefits of promoting food intake rather than finding ways to reduce consumption [47]. The results obtained in research conducted by Băltescu [48] show young people's willingness to eat in green restaurants, as well as their availability to allocate higher amounts of money for the consumption of healthy foods. Green practices in restaurants include the following dimensions: energy efficiency, water conservation, pollution prevention, and environmental health, reuse and recycle programs, green purchasing, green materials, sustainable foods, and green designs of buildings and space [48]. In research, different topics were covered, for example, the influence of portion size in the context of minimizing food wastage [49].

Sustainability in simple words is "the ability to sustain". Sustainability of manufacturing processes is a prerequisite in reducing their environmental impacts. Food consumption has a major environmental impact right from growing the food until it is consumed. Food production involves considerable energy and resource inputs. Therefore, there is a strong need to focus on sustainable manufacturing toward achieving long-term sustainability goals in food production. Many hospitality studies have attempted to explore the factors that prompt restaurants' adoption of sustainable practices $[50,51]$. In particular, researchers have identified critical factors (e.g., stakeholder pressure, public concerns, regulatory forces, competitive advantage, top management commitment, managers' values, beliefs) affecting environmental sustainability and behavior $[52,53]$.

Several studies focused on sustainability practices from the owner's or management's perspective, as well as focused on green restaurants or hotels in different countries [54-59]. There are a few studies [60-64] about sustainability practices in restaurants from the viewpoint of consumers of green restaurants, that are specific. There is little or no research from the viewpoint of consumers of common restaurants. This study assumes that clients can also influence restaurant's sustainable practices. For this study, consumers from Poland and Lithuania were selected as representatives of Eastern Europe. These countries are differentiated in terms of area, population, and population density, as well as in terms of the size of cities and the number of catering establishments (70,108 in Poland vs. 8445 in Lithuania in 2018). In the last two decades, significant changes occurred in both countries, including political and economic changes $[65,66]$. At that time, the food service market became similar to Western markets, both in the number of catering establishments and in their approach to the customer $[1,67]$.

Recent trends in the food service business are elusive, like the sustainability approach in restaurants. Our paper closes the gap regarding the sustainability in commercial restaurants (not green restaurants). The study aimed to observe and understand the behavior of contemporary consumers in restaurants. To achieve that, the researchers have identified and analyzed consumer choices in Warsaw (Poland) and Kaunas (Lithuania). The service quality has been evaluated using a comprehensive approach which included the quality of meals and service testing along with a sustainability practices analysis in selected restaurants.

The purpose of this study was to identify and analyze consumer choices and evaluate service quality, including comprehensive approach, i.e., the quality of meals and service, and sustainability practices among restaurants in Warsaw (Poland) and Kaunas (Lithuania).

\section{Materials and Methods}

\subsection{Questionnaire Research}

The quality of services can be examined in different ways. These include using the SERVQUAL or the DINESERV model $[68,69]$. They can also be dedicated methods $[63,70-73]$. The questionnaire was designed based on literature and previous research $[68,69]$ and was validated by means of a pilot study with 20 people. All problems have been identified, for example, unintelligible questions and questionnaire construction. The questionnaire has been completed and amended. The data was collected among customers of restaurants in Poland and Lithuania. The research was carried out in large cities: Warsaw and Kaunas. These cities are the places where new consumer trends come to the surface and where these trends spread around the country. Consumers in cities have relatively high disposable incomes, are well educated, and represent a higher level of consumer awareness [74]. Participants were 
randomly recruited by trained investigators in shopping malls and supermarkets [75]. Every third consumer that came into view was recruited. Eight hundred consumers were recruited from each city, resulting in a final enrollment of 600 participants [76]. Taking into account the eating habits of residents, the survey was conducted during the hours of 13:00-16:00 and 17:00-20:00, two periods when most people eat out. The respondents completed the questionnaire in the presence of the interviewer so that they could ask additional questions at any time or ensure the content of the question was properly understood. Complete questionnaires $(n=1200)$ were analyzed.

The questionnaire structure is presented in the Table A1 (Appendix A). The questionnaire consists of two parts. The first part of the questionnaire consists of 12 questions relating to the behavior of respondents in the restaurant. The questions pertained to the reasons and frequency of visiting the restaurant, the length of time spent eating at the restaurant, the type and frequency of meals consumed, as well as an evaluation of different features of the restaurant and identification of reasons for complaint about catering services. The second part of the questionnaire relates to the respondent's sociodemographic details.

\subsection{Characteristics of Respondents}

Characteristics of the respondents are presented in Table 1. Our research was conducted using a sample of 1200 adult respondents, including 600 Poles and 600 Lithuanian. The respondents were free to participate in the research. Most of the respondents from both nationalities were under 25 years old, with higher education. In Poland and Lithuania, a significant percentage were people from large and medium urban agglomerations, as well as the employed. In both groups, a small percentage were people with low financial status: in Poland 1.29\%, in Lithuania 3.57\%. A small percentage were people with food allergies: in Poland 19\%, in Lithuania about 10\%.

Table 1. Characteristics of the surveyed sample of respondents.

\begin{tabular}{|c|c|c|c|c|c|}
\hline \multirow{2}{*}{$\begin{array}{l}\text { Population Features } \\
\text { Nationality }\end{array}$} & \multirow{2}{*}{$\begin{array}{l}\text { Group } \\
-\end{array}$} & \multicolumn{2}{|c|}{ Number of Respondents } & \multicolumn{2}{|c|}{ Percentage of Respondents } \\
\hline & & Poles & Lithuanians & Poles & Lithuanians \\
\hline Total & - & 600 & 600 & 100 & 100 \\
\hline \multirow{2}{*}{ Gender } & Women & 300 & 300 & 50.00 & 50.00 \\
\hline & Men & 300 & 300 & 50.00 & 50.00 \\
\hline \multirow{2}{*}{ Age } & 18-25 years old & 414 & 402 & 69.00 & 67.00 \\
\hline & $26-50$ years old & 186 & 198 & 31.00 & 33.00 \\
\hline \multirow{2}{*}{ Education } & Secondary school & 294 & 114 & 49.00 & 19.00 \\
\hline & Higher education (university) & 306 & 486 & 51.00 & 81.00 \\
\hline \multirow{2}{*}{ Marital status } & Single & 500 & 456 & 83.33 & 76.00 \\
\hline & Married & 100 & 144 & 16.67 & 24.00 \\
\hline \multirow{4}{*}{ Dwelling place } & Village & 93 & 125 & 15.50 & 20.83 \\
\hline & City up to 100,000 inhabitants & 111 & 162 & 18.50 & 27.00 \\
\hline & City $100,000-500,000$ inhabitants & 66 & 135 & 11.00 & 22.50 \\
\hline & City over 500,000 inhabitants & 330 & 178 & 55.00 & 29.67 \\
\hline \multirow{4}{*}{ Inhabitation: } & Alone & 85 & 136 & 14.17 & 22.67 \\
\hline & Couple & 138 & 212 & 23.00 & 35.33 \\
\hline & Partly alone/partly with family & 48 & 96 & 8.00 & 16.00 \\
\hline & With family/friends & 329 & 156 & 54,83 & 26.00 \\
\hline \multirow{2}{*}{ Occupation } & Employed & 430 & 306 & 71.67 & 51.00 \\
\hline & Unemployed & 170 & 294 & 28.33 & 49.00 \\
\hline \multirow{5}{*}{$\begin{array}{l}\text { Financial status in } \\
\text { own opinion }\end{array}$} & Very good & 70 & 48 & 11.67 & 8.00 \\
\hline & Good & 352 & 232 & 58.67 & 38.67 \\
\hline & Not good not bad & 170 & 298 & 28.33 & 49.67 \\
\hline & Bad & 8 & 20 & 1.33 & 3.66 \\
\hline & Very bad & 0 & 0 & 0.00 & 0.00 \\
\hline \multirow{2}{*}{ Food allergy } & Yes & 114 & 54 & 19.00 & 9.00 \\
\hline & No & 486 & 546 & 81.00 & 91.00 \\
\hline
\end{tabular}




\subsection{Data Analysis}

The statistical analysis of the results were performed using Statistica software (version 13.3 PL; StatSoft Inc., StatSoft, Krakow, Poland). ANOVA, Student's $t$-test, and multi-dimensional cluster analysis were used. The significance of differences between the values was determined at a significance level of $p<0.05$. For a more comprehensive and full presentation of the factors affecting the choice of restaurant, as well as characteristics of consumer opinion about the poor quality of meals and the service, a multidimensional cluster analysis and principal component analysis (PCA) was used. Calculations made using cluster analysis enabled the interpretation of restaurant selection factors. Two aspects were analyzed: (1) Elements regarding the quality of meals and restaurant services; and (2) sustainable practices used by the restaurant. Cluster analysis is a group of multivariate techniques whose primary purpose is to group objects [77,78]. Its aim is to divide a set of the data into groups of similar characteristics. In our case, similar responses were obtained if consumers were grouped.

Calculations made with PCA enabled the analysis of negative consumer experiences on the quality of meals and the quality of service, indicating the main factors affecting consumer experience. The results of the cluster analysis were presented graphically on the dendrograms and the results of the PCA analysis is shown on the PCA biplots. PCA is a statistical tool for dimension reduction. The large datasets (in our case negative consumer experiences about the quality of meals and the quality of service) was transformed into a smaller one that still contains most of the information in the large set. The objective of PCA is to find common factors, the so-called principal components (in our case factors influencing consumers' opinion). A correlation matrix was used (the variances of individual variates differed considerably). As part of data pre-treatment, correlation eigen values were calculated. This was used to determine the number of main factors affecting results [79]. The analysis of results was done separately for Polish and Lithuanian consumers.

\section{Results}

\subsection{Consumer Habits in the Range of Use of Restaurant Services}

The frequency of using catering services by Polish and Lithuanian consumers was differed statistically significant (Student's $t$-test; $p=0.0000$ ). However, in both countries, most consumers answered less than once a week (Poles $46.4 \%$, Lithuanians $43.5 \%$ ). Significantly more Poles than Lithuanians ate in restaurants once a week $(24.0 \%, 18.9 \%$, respectively), three times a week $(10.4 \%$, $7.5 \%$, respectively), and every day $(2.5 \%, 0.6 \%$, respectively). However, significantly more Lithuanians than Poles dined in restaurants twice a week $(12.3 \%, 9.5 \%$, respectively) and three or four times a week $(11.7 \%, 2.2 \%$, respectively). The answers provided were dependent only for a few analyzed sociodemographic factors. In Poland there were three factors (among nine in total) which determined answers (Dwelling place $p=0.0011$, Inhabitation $p=0.0229$; Financial status $p=0.001281$ ), but two in Lithuania (Marital status $p=0.00900$; Financial status $p=0.00980$ ).

When choosing restaurants, both Poles and Lithuanians, have checked website information (Poles $74.3 \%$, Lithuanians $78.3 \%$ ) and they relied on friends' recommendations (62.3\%, 55.3\%, respectively). However, significantly more Lithuanians than Poles used social media to choose restaurant $(39.7 \%$, $2.0 \%, p=0.00000)$, and Poles choices are often based on advertisement $(18.0 \%, 10.0 \%, p=0.01030)$. Other sources of information about restaurants (leaflets, professional contacts, phone applications, impulse purchasing, etc.) were given in both countries by less than $3 \%$ of respondents.

The declarations of respondents from both countries regarding the reasons for using restaurant services were similar. Customers use the restaurants during family meetings (Poland $33.7 \%$, Lithuania $38.3 \%)$, business meetings $(8.3 \%, 9.7 \%$, respectively) and for satisfying hunger $(35.3 \%$, $29.7 \%$, respectively). Significantly more Poles than Lithuanians declared private meetings $(66.3 \%$, $19.7 \%$, respectively, $p=0.00000)$, meetings with friends $(85.0 \%, 66.3 \%$, respectively, $p=0.00000)$. While Lithuanians more often declared other goals, such as: lack of culinary skills in preparing favorite 
dishes, lack of time, springboard from everyday life and the desire to recall holiday memories $(8.3 \%$, $1.3 \%$, respectively, $p=0.00006$ ).

In the restaurant, Poles and Lithuanians spend a similar length of time. In both countries, $45-60 \mathrm{~min}$ as time of visit in restaurants were declared most often (45.3\% of Poles and $40.3 \%$ of Lithuanians). Then the time $30-45 \mathrm{~min}$ was mentioned $(22.0 \%, 29.0 \%$ of respondents, respectively). A small group of Polish and Lithuanian respondents spent more than one hour on a meal $(22.7 \%, 17.3 \%$, respectively), or a very short time, i.e., $15-30 \mathrm{~min}(8.3 \%, 9.3 \%$, respectively). In both countries, Poland and Lithuania, the fewest number of respondents declared time up to $15 \mathrm{~min}$ or another $(1.0 \%)$.

Respondents in both countries were asked what kind of meals and how often they eat in restaurants (Table 2). In Poland, the most often consumed meals were sandwiches (usually three times a week). In Lithuania it was desserts and alcohol drinks, which were consumed twice a week. The dominant consumption (fashion) most rarely concerned, in both countries, meals such as cold and hot breakfast (Median 0), vegetarian meals (Median 0) and, in Lithuania, also sandwiches (Median 0). However, other meals were consumed mainly once or fewer times a week. Slight differences between the average and median testify to small discrepancies in consumer opinion.

Table 2. Frequency of dish and beverages consumption at restaurant by respondents.

\begin{tabular}{ccccccccc}
\hline \multirow{2}{*}{ Type of Meals } & \multicolumn{3}{c}{ Poles $(\boldsymbol{n = 6 0 0 )}$} & \multicolumn{5}{c}{ Lithuanians $(\boldsymbol{n}=\mathbf{6 0 0})$} \\
\cline { 2 - 9 } & Average & Q25 & Median & Q75 & Average & Q25 & Median & Q75 \\
\hline Cold breakfast & $0.96^{*}$ & 0 & 0 & 0 & 1.20 & 0 & 0 & 3 \\
Hot breakfast & 2.07 & 0 & 0 & 5 & 1.56 & 0 & 0 & 4 \\
Soups & 3.38 & 0 & 5 & 5 & 3.36 & 0 & 5 & 5 \\
Main course & 4.41 & 4 & 5 & 5 & 4.22 & 4 & 5 & 5 \\
Fast food & 4.04 & 4 & 5 & 5 & 3.51 & 1 & 5 & 5 \\
Cakes/pie & 3.34 & 0 & 5 & 5 & 3.01 & 0 & 5 & 5 \\
Sandwiches & 2.37 & 0 & 3 & 5 & 1.98 & 0 & 0 & 5 \\
Salads & 3.21 & 0 & 5 & 5 & 3.50 & 2 & 5 & 5 \\
Desserts & 3.91 & 4 & 5 & 5 & 2.85 & 0 & 4 & 5 \\
Vegetarian' meals & 2.31 & 0 & 0 & 5.00 & 1.64 & 0 & 0 & 5 \\
Non-alcoholic drinks & 3.79 & 3 & 5 & 5 & 3.19 & 0 & 5 & 5 \\
Alcohol drinks & 4.06 & 4 & 5 & 5 & 2.61 & 0 & 4 & 5 \\
\hline
\end{tabular}

* Frequency of consumption of meals: (1)—every day, (2)—four times a week, (3)—three times a week, (4)—twice a week, (5)—once or less than once a week, (0)—never; Q25-lower quartile; Q75-upper quartile.

\subsection{The Elements Affecting the Use of Restaurant Services by Respondents}

The study identified elements that in both countries play an important role in determining the choice of catering establishments. The elements were analyzed in the context of meal quality and service quality (19 options) and application of restaurant's sustainable practices (nine9 options). The respondents could indicate any number of factors. The calculations using multivariate cluster analysis identified three groups of elements influencing consumer decisions in Poland, and four groups in Lithuania (Figure 1). For Polish consumers, the most important elements were presented in cluster 1 , and their selection was confirmed by the largest consumer group $(63.2 \%$ on average). They were factors: palatability and quality of meals, price, location of the restaurant, and recommendation of friends. In cluster 2, the collected elements (Figure 1a) were indicated by an average of $27.4 \%$ for consumers. However, in cluster 3, there were collected elements (Figure 1a) that have least affected the choice of gastronomic establishments (on average 5.4\%). On the other hand, in Lithuania, two elements were classified into cluster 1 (Figure $1 \mathrm{~b}$ ). These were of the greatest importance to consumers, i.e., price and the quality of meals, which were indicated by an average of $67.5 \%$ for respondents. The elements collected in cluster $2(42.2 \%)$ and cluster $3(32.6 \%)$ were of moderate importance (Figure 1b). On the other hand, cluster 4 presented the elements with the weakest significance for consumer decisions regarding the choice of catering establishments in Lithuania (9.9\%). 


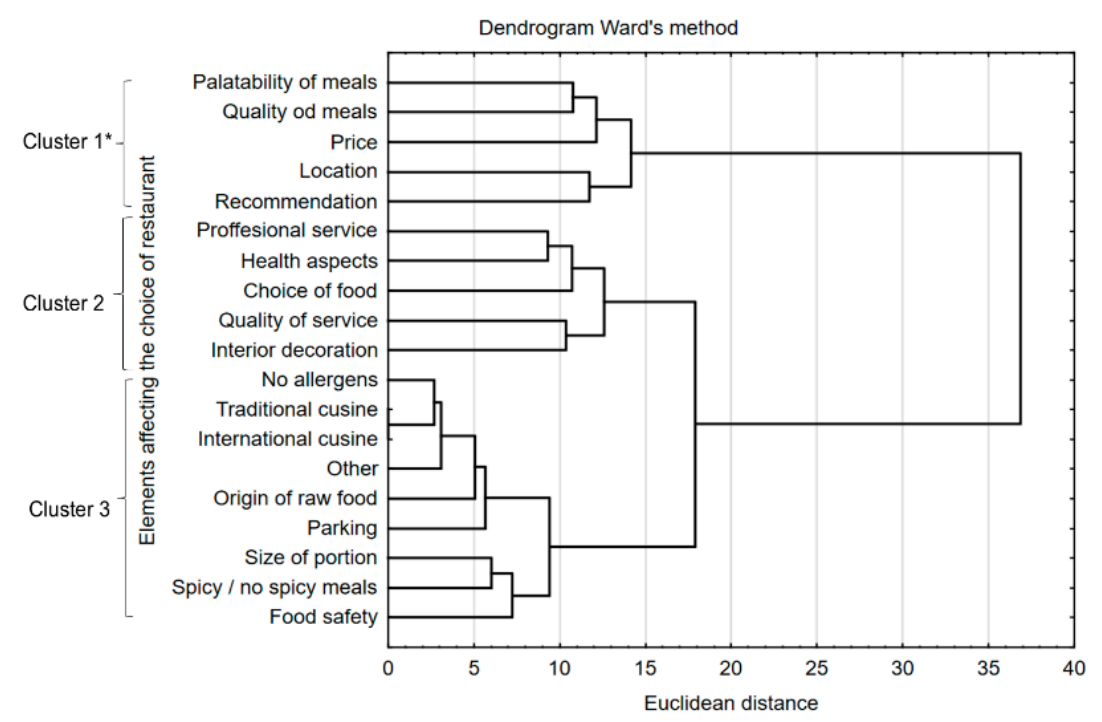

(a) Poland

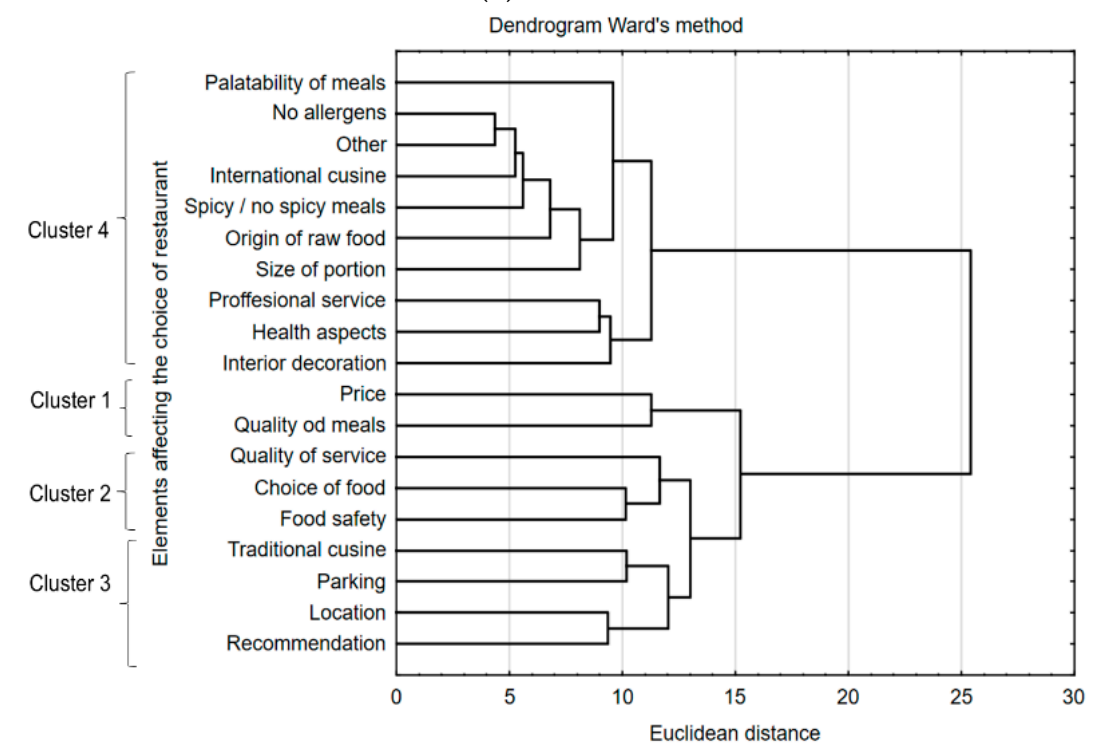

(b) Lithuania

Figure 1. Elements determining the use of restaurant services concerning food, service, and restaurant.

* Clusters numbered according to their importance to consumers.

In case of sustainable approach practices used in restaurants, respondents had a choice of nine different options. The calculations using multivariate cluster analysis identified four groups of elements influencing consumer decisions in Poland, and three groups in Lithuania (Figure 2).

In Poland (Figure 2a), the most important for consumers was using local ingredients and reusable cutlery (cluster 1,59\%), followed by the use of seasonal ingredients and alternative protein sources (cluster 2, 32.2\%). Elements collected for clusters 3 and 4 played a small role in consumers' decisions in choosing restaurants $(26 \%, 10 \%$, respectively, in Poland and Lithuania). In Lithuania, more often than in Poland (Figure 2b), a sustainable approach used in restaurants was taken into account when choosing restaurants. The most important element was the use of reusable cutlery (cluster 1,86\%), as well as seasonal and local ingredients (cluster 2, 59\%). Other elements were the least important for respondents when choosing a restaurant (cluster 3, 25\%). 


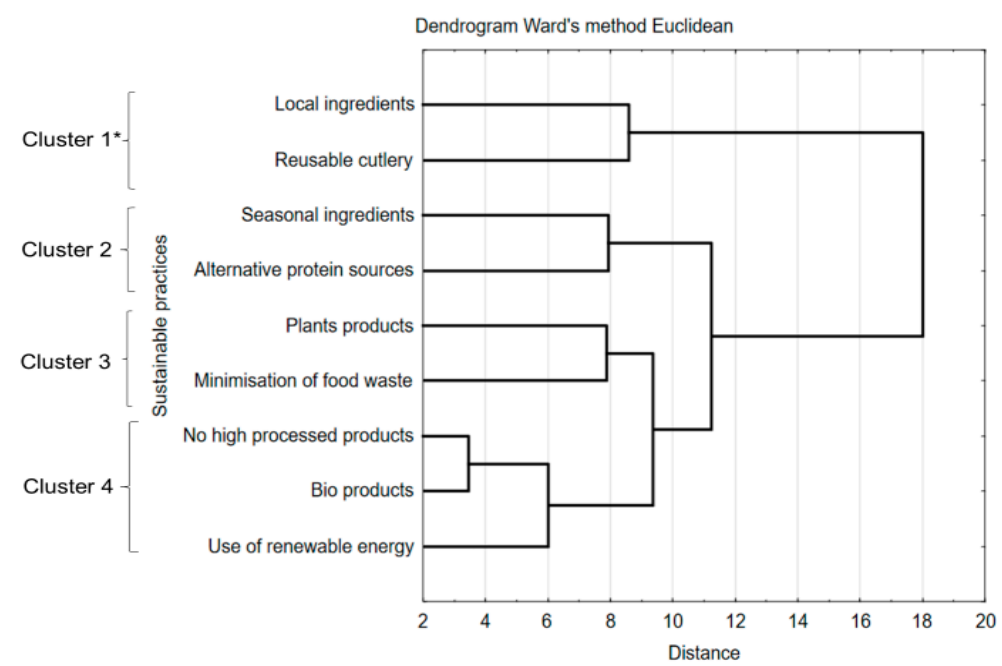

(a) Poland

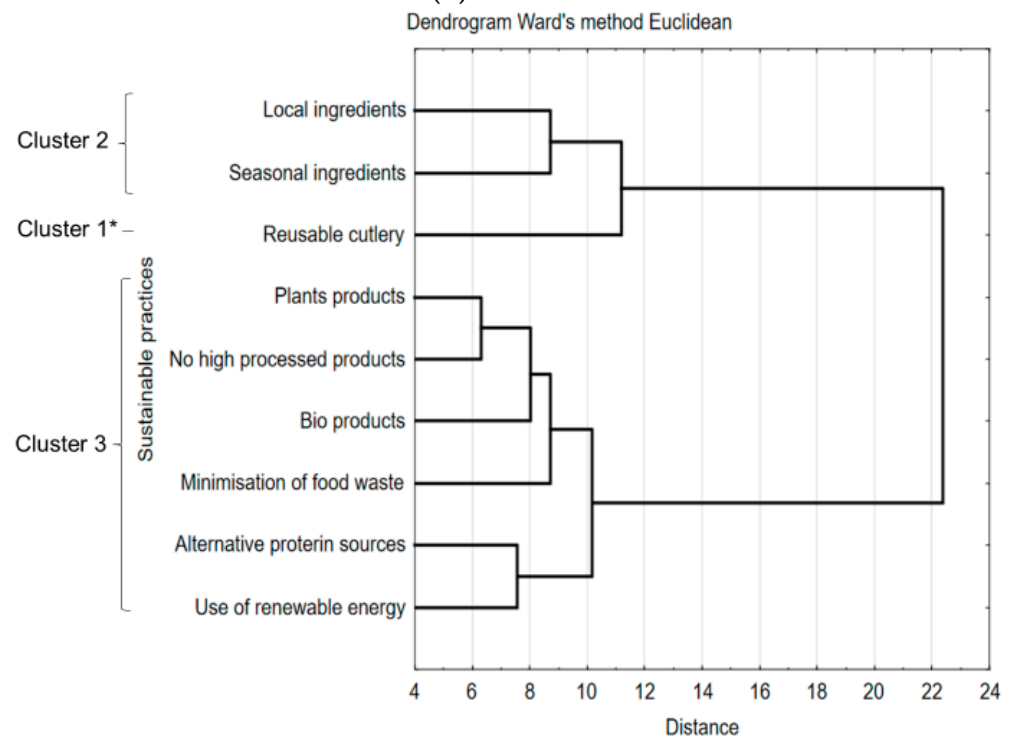

(b) Lithuania

Figure 2. Elements determining the use of restaurant services regarding sustainable practices. ${ }^{*}$ Clusters numbered according to their importance to consumers.

\subsection{Evaluation of Quality of Restaurants in Poland and Lithuania}

In the research, special attention was devoted to learning about consumers' opinions on the quality of meals served in catering establishments and the quality of gastronomic services. Polish and Lithuanian respondents assessed the quality of services in restaurants [(1) very good ... (5) poor] in terms of interior elements, customer services, and sustainability approach (Table 3). Both Polish and Lithuanian respondents rated the quality of interior elements and customer service at a good level. However, Poles rated the cleanliness of the dishes, the availability of toilets, and the quality of alcoholic drinks better than Lithuanians, as very good. Food quality in Poland and Lithuania was assessed as very good and good. However, Poles rated that some features, such as the availability of menu, taste, temperature of meals, possibility to take away, better than Lithuanians, as very good. Implementation of sustainability approach practices were rated to be relatively the worst. The use of alternative protein sources, serving plant meals, and using reusable plates and cutlery was rated good in both countries. In case of other assessments, differences between countries were found. In Lithuania, respondents rated aspects like the use of seasonal and local raw materials during meal preparation, serving bio 
meals, as well as using renewable energy in restaurants as very poor. In Poland, on the other hand, restaurants had the lowest ratings for obtaining the minimization of food losses (Table 3).

Table 3. Evaluation of restaurant services by respondents.

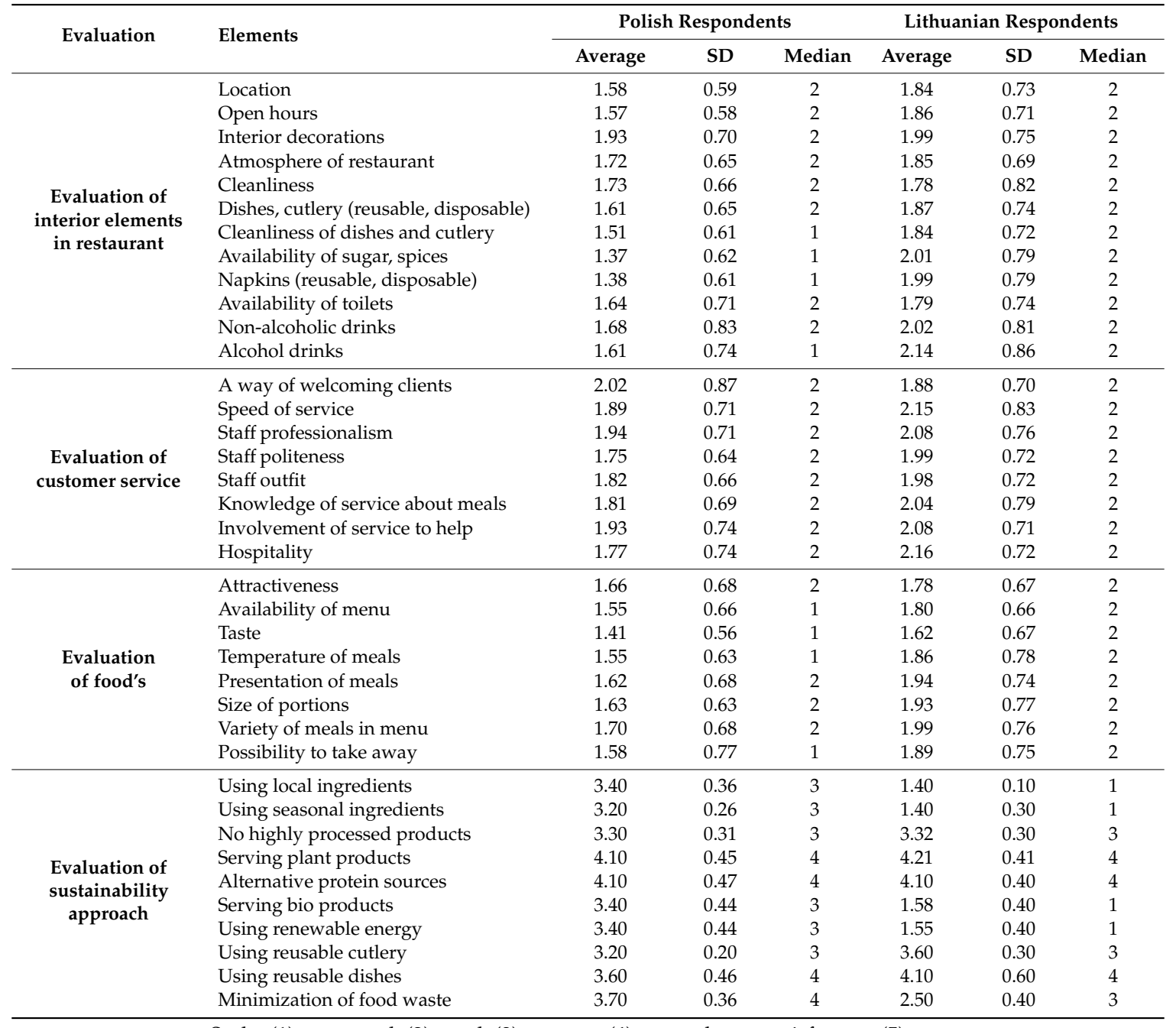

Scale: (1) very good, (2) good, (3) average, (4) somewhat unsatisfactory, (5) poor.

\subsection{Complaints about Restaurant Services and Foods by Respondents}

Among the reasons for complaints about services in restaurants, consumers could indicate any number of responses. Similar declarations regarding waiter service complaints were recorded in both countries (in Poland 63.4\%, in Lithuania 51.0\%). In both countries, similar $(p>0.05)$ answers also focused on touching the edge of the glass (Poland 8.7\%, Lithuania 13.7\%) and touching the cutlery $(7.0 \%$, $11.3 \%$ respectively). Other reasons for complaints of restaurant service differed significantly. In Poland, order mistake was mentioned significantly more often than in Lithuania $(26.7 \%, 18.7 \%$ respectively, $p=0.01926)$. However in Lithuania, complaints were more frequently mentioned in the areas of: speed of service $(27.3 \%, 14.0 \%, p=0.000051)$, too small of a portion $(11.0 \%, 2.3 \%, p=0.00002)$, unkindly personnel $(16.7 \%, 2.3 \%, p=0.00006)$, dirty tables, dishes, and cutlery $(15.7 \%, 6.3 \%, p=0.000246)$, as well as mistakes in payment $(7.3 \%, 2.7 \%, p=0.008677)$.

In order to determine the main factors conditioning service complaints in restaurants, as well as to determine the relationship between them, PCA calculations were performed (Figure 3). In both countries, three main groups of factors were identified. In both countries, the first main factor was the low proportion of complaints due to touching the edge of the glass and the cutlery with bare hands. However, the other two main factors differed depending on the assessed country. In Poland, 
the second main factor of concern was the cleanliness of tables, dishes, and cutlery, as well as size of the portions, while in Lithuania consumers were concerned by the long waiting time for a meal, and order mistakes. The third main factor was, in Poland, order mistakes and, in Lithuania, mistakes in payment and the cleanliness of tables, dishes, and cutlery. Other reasons for complaints have only slightly affected the opinion of consumers about the quality of service in restaurants. In both countries, there were only positive relationships between factors, i.e., the indicated reasons of complaints were mutually correlated.

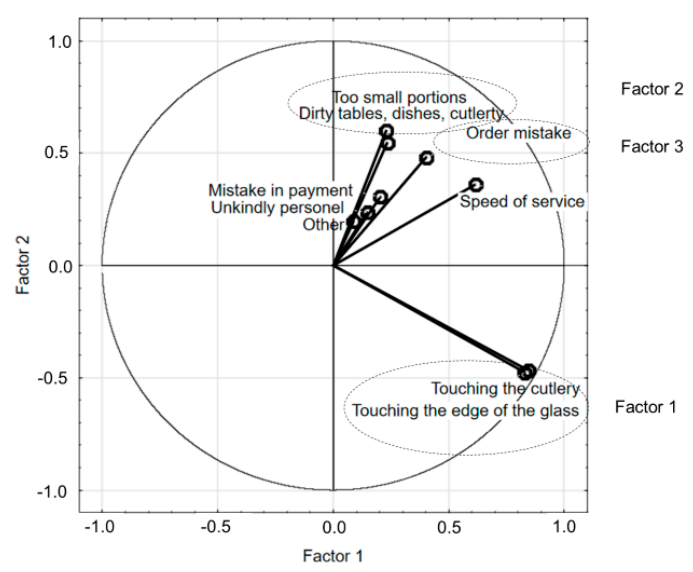

(a) Poland

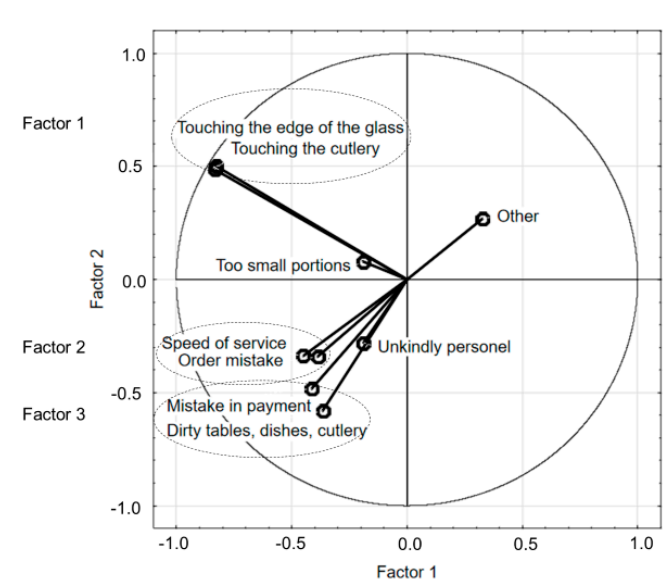

(b) Lithuania

Figure 3. Negative consumer experiences regarding the quality of service in restaurants.

Most consumers who answered questions on the frequency of buying meals of poor healthy quality have declared answer 'never' (in Poland 62.2\%, in Lithuania 57.7\%). Other responses regarding negative experiences in restaurant services focused on situations which have occurred from time to time. The most popular reason of complaint in Poland was the strange taste of meals (70.3\%). Then, respondents indicated the low temperature of hot meals (42.3\%), abdominal pain after a meal $(31.7 \%)$, and finding foreign bodies (30.0\%). The fewest comments were regarding food poisoning $(11.0 \%)$, finding molds $(2.3 \%)$, and others $(2.3 \%)$. In Lithuania most consumers indicated low temperature of meals $(42 \%)$, then strange taste $(26.3 \%)$. Other complaints were indicated by a small group of consumers: food poisoning $(14.0 \%)$, abdominal pain after a meal $(14.0 \%)$, finding foreign objects $(12.0 \%)$, molds $(4.6 \%)$, and others $(7.3 \%)$. Significant statistical differences in consumer comments on restaurant service quality was related to finding foreign bodies $(p=0.0000)$, abdominal pain after a meal $(p=0.0000)$, and strange taste $(p=0.0000)$, and were more often declared in Poland than in Lithuania.

In order to deepen the analysis of consumer experience about the quality of meals, PCA was performed. The purpose of the analysis was to determine the main factors affecting consumers' opinion about meals and to examine the relationship between them. The results of the PCA showed that the experiences of Polish consumers were associated with the occurrence of three and, in the case of Lithuanian consumers, four main factors, as shown in Figure 4.

The first main factor for Polish consumers was strange taste. The second was the joint occurrence of finding foreign bodies in meals and food poisoning, the third was abdominal pain after a meal and too low a temperature of hot meals. Other factors have only slightly explained the opinion of Polish consumers on meals. Due to the location of the factors in the individual quarters of Figure 4a, it follows that consumers who chose the first main factor-strange taste, have not combined it with food poisoning or finding a foreign body in a meal (i.e., negative correlation).

In Lithuania, four main factors that explain consumer opinion about the quality of meals in restaurants have been identified. The first main factor was the low temperature of meals, the second combined strange taste and finding foreign objects, the third abdominal pain after a meal, and the fourth is food poisoning. Other factors did not influence the opinion of consumers on meals. Analyzing 
the location of the factors in opposite quadrants in Figure $4 \mathrm{~b}$, a negative correlation between factors 1 , 3 , and 4 should be stated. This means that consumers who declared receiving a hot meal with too low a temperature did not associate it with abdominal pain after a meal and food poisoning. In contrast, consumers who indicated factor 3 , i.e., abdominal pain after a meal, combined it with factor 4 , i.e., food poisoning (positive correlation).

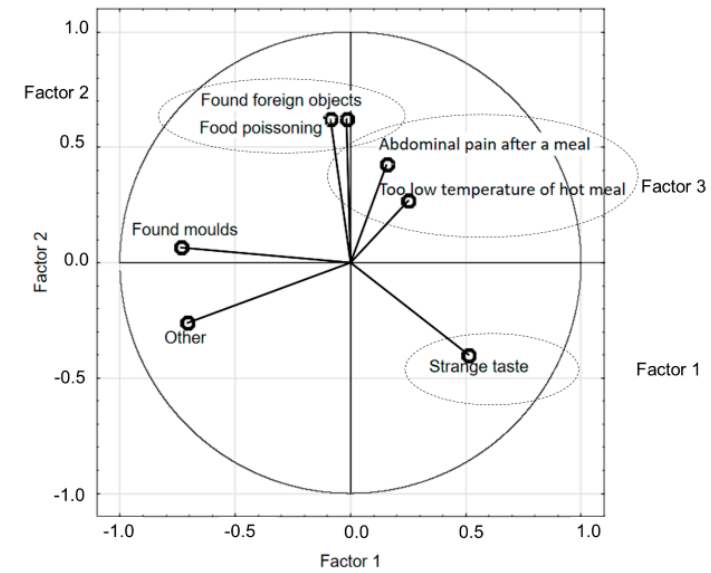

(a) Poland

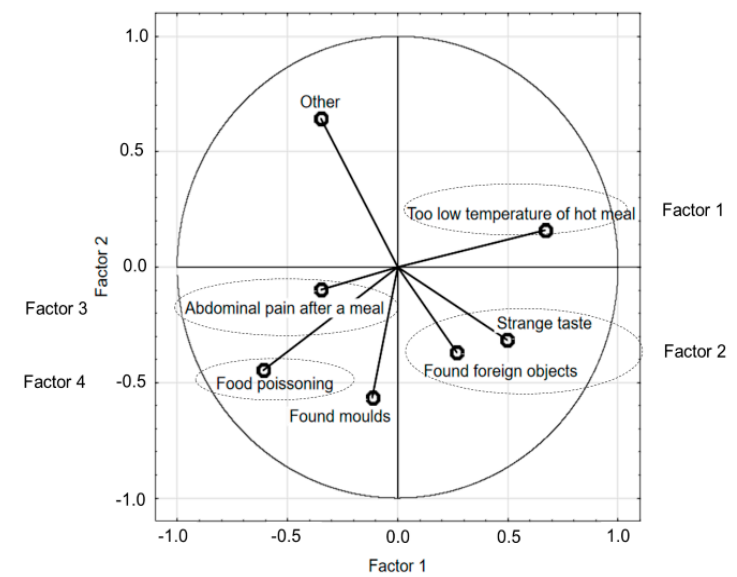

(b) Lithuania

Figure 4. Negative consumer experiences regarding the quality of meals served in restaurants.

\section{Discussion}

Most consumer behavior in restaurants is similar in Poland and Lithuania, for example, the frequency of eating in restaurants once or less than once in a week (Poles $46.4 \%$, Lithuanians $43.5 \%$ ). Other authors $[67,80]$ have illustrated similar dependencies. Slightly more often, men and far more often young people, as well as those with middle and higher income had used restaurant services. When choosing restaurants, both Poles and Lithuanians, checked on website information (74.3-78.3\%) and relied on friends' recommendations $(62.3-55.3 \%)$. The reasons for using catering services were similar as some authors have stated [81,82]. Customers in both countries use the restaurants during different meetings (families, business meetings, meetings with friends) and for satisfying hunger.

The research contributes to the hospitality literature by taking the first step to explore the consumer's multidimensional opinion about food quality, service, and the restaurant's sustainable practices. In this study, consumers' experiences were identified which refer to the quality of food and service in restaurants, thereby opening research for future studies to consider the effect of eating out on consumer's satisfaction. Prior research tended to focus on food quality and the service quality, while overlooking sustainable practices in restaurant. Many authors $[75,83,84]$ stated that the quality of food and services are the most important determinants of customer estimation of catering establishments and it is, thus, most important to identify market trends and match them with an offer in order to satisfy the requirements of consumers.

The previous research of some authors [26,85-87] have focused on food quality and price of restaurant service, as well as their influence on customer food satisfaction as a consequence for choice of restaurant. Authors have suggested that if the food quality increases, then the customer dining satisfaction will also increase [85]. On the other hand, the higher the price of restaurant services, the higher consumer expectations are regarding the quality of meals [26].

Many factors influencing consumer satisfaction were revealed. The current study responds to this call from the literature by taking into consideration a large number of the revealed factors affecting consumer satisfaction and the choice of restaurant. In case of the factors related to the quality of meals and the quality of customer service, based on the cluster analysis calculation which was made, it was indicated that, in both countries, different groups of factors decided to choice 
of restaurant by consumers. However, in the countries surveyed they were combined with other features, i.e., in Lithuania only with the price, and in Poland with the price and a few others, which may indicate greater requirements of Polish consumers for restaurant services. The other groups of restaurant-selecting factors were different. For example, Poles valued palatability of meals, restaurant recommendations by friends, and location of establishments much more than Lithuanians. Lithuanian consumers have paid more attention to the choice of meals and their food safety. Differences in the approach of Polish and Lithuanian consumers emphasized their national diversity, despite the neighborhood and common history. Our results have an applicative nature. The specific reasons for choosing a restaurant are useful for owners considering opening a new restaurant or making changes to their day-to-day operations. Acting based on the research results can help restaurant owners in achieving business success or in supporting management. Previous literature [21-25] have provided a useful reference for further research connected with consumers' satisfaction. However, there are still some deficiencies. The consumer's assessment of sustainability practices in restaurants is a sample of it. Only in some articles was the level of environmental sustainability awareness of restaurant employees determined [88]. There is a lack of research with customer' opinion about this topic. In this context, our research is of pioneering cognitive and educational significance. Some authors $[88,89]$ have stressed that increased environmental education is the most convenient solution for mitigating the problems.

It is now widely recognized that food consumption has a major sustainability impact. Thus, it is not surprising that there is a strong interest in promoting sustainable food consumption practices. One of the most important elements of the sustainable approach, also in restaurants, is the reduction or elimination of meat consumption [90,91]. However, interpretation of the results by means of multidimensional cluster analysis showed that, in both countries, there is little consumer interest in vegetarian meals as well as for alternative protein sources. These results, on the one hand, emphasized similar culinary preferences of Poles and Lithuanians to meals containing meat and correspond to the lack of readiness to give up meat consumption, as demonstrated by research in Finland [92]. On the other hand, in the context of reports of significant energy consumption rates, particularly in the slaughter, animal processing, and animal product utilization sectors, they show a lack of awareness of climate change caused by the production of meat meals [47].

The authors [93] suggest that modifying portion size in restaurants could be an effective tool for stimulating vegetable consumption and, consequently, healthy and sustainable diets. In contrast to the preferences for consumption of meat meals, the high share in the concentration of consumption of local and seasonal food testifies to the fact that the surveyed Polish and Lithuanian consumers only partially match contemporary environment-friendly consumption trends, as well as the consumption of locally-sourced or organic food [25,37,51]. Food waste is an important topic that is of environmental and societal concern. One method of reducing food waste is for clients to take their restaurant leftovers home for future consumption [94].

Another method can be to serve meals yourself and adjust the portion size to your individual needs. In both countries, waste minimization has been classified as clusters of minor importance while making decisions about choosing a restaurant. On the other hand, reducing food waste was not important for the consumers. As other authors [95] have stated, consumers were not accustomed to asking for leftovers as standard practice in restaurants. The authors of this publication were in agreement with other authors to devote more attention to waste reduction and highlight this problem among a wide range of interested persons.

According to some authors [96], a large percentage of restaurateurs plan to invest in energy-saving equipment and water-saving devices. The results of statistical calculations indicated that the use of alternative energy sources in restaurants was almost not taken into account when choosing a restaurant. Research on this subject is even more limited. Topics that have been studied include the role of eco-innovations in the choice of restaurants [97], the types of eco-innovations adopted by restaurants and by hotels $[98,99]$, and the importance of using eco-innovations in the physical environment design of restaurants to generate an innovative atmosphere [100]. Therefore, efforts should be made to not 
only optimize the energy and resource usage during the food production processes [101], but also to raise eco-innovation knowledge among consumers and their responsibility for environmental change processes. Our results have indicated that Polish and Lithuanian restaurant managers do not use environmentally friendly practices. They are not aware that the food purchases of food service are the largest source of environmental impact [17].

The cluster analysis calculations, regarding the use of reusable cutlery and plates, avoiding plastic (e.g., natural or reusable drinking straws, reusable napkins, cutlery, and plates), were interesting. There are only a few publications researching this subject [102,103]. The use of reusable cutlery and plates has been very positively appreciated by Polish and Lithuanian consumers. In both countries, the use of such tableware was very important and, in Lithuania, it was the most important factor in choosing a restaurant. This demonstrates, on the one hand, similar preferences and, on the other hand, great awareness of customers to use environmentally friendly cutlery and tableware. This approach of clients may in future get their approval and understanding for new initiatives for making sustainable cutlery and crockery, e.g., from areca palm and coconut tree [104].

Negative consumer experiences of meal quality and service are reported worldwide $[105,106]$. Eating a healthy diet and eating a safe food were perceived as the most important food-related goals [107], as well as food safety is one of the credence attributes for food [108]. Our own research results are similar to the results of other authors.

An in-depth analysis of the reasons for complaints by means of multidimensional calculations has enabled us to indicate the main reasons for complaints and compare them between the examined countries. PCA calculations have indicated the main problems regarding meal quality and service quality. The topic of meal quality and safety in customers' opinion was rarely discussed in the literature on the subject and was usually addressed in a narrow scope [109]. Only a few works (e.g., [81,82]) have presented this topic in an exhaustive way. Examining negative consumer experiences has practical implications and can support restaurant managers.

The findings of Liu et al. [107] suggested that the restaurant management can improve customer dining satisfaction focusing on the food quality of their customers and enhancing their response to customers who have experienced a low level of food quality.

The conducted research indicates places for the necessary improvement of the quality of meals made in restaurants. Only a few studies have identified specific reasons for consumer complaints. The most often reported cases of complaint were the presence of foreign objects (42.4\%) [110], and the most frequently found foreign bodies were pests, glass, and metals [111,112]. In Poland and Lithuania, the presence of foreign bodies was also a significant cause of negative consumer experiences. This indicates that foreign bodies are fairly common and, because of the following meal quality complaints, particularly easy to notice. The main factors for complaints regarding the quality of meals differed between the countries. In Poland, consumers were concerned about the quality of meals, e.g., strange taste, while in Lithuania, it was the food safety e.g., too low a temperature of hot meals. The explanation for these differences can be the individual approach by consumers and their different culture. According to Jahandideh et al. [113], there is no universal pattern for consumer complaint behavior. The authors have pointed out that the individual consumers from different cultures have diverse needs and expectations when they complain of restaurant services. It is worth emphasizing that a common reason for complaints regarding catering services are abdominal pain after a meal, which is typically caused due to meal unsafety. In both countries this reason had a further position in the classification of reasons for complaints.

Quality of service is a crucial aspect in the success of restaurant business and it becomes more and more crucial to attract new customers, retain existing ones, and remain competitive and profitable [114]. Evaluation of the restaurant services quality involves a fundamental activity with a relation to several viewpoints. First of all, to evaluate consumers' expectations and perceptions with relation to the fundamental service characteristics and, in the second instance, to identify management criticalities regarding the delivered service [115]. The results of our research can be helpful in these aspects. 
The PCA calculations have showed that apart from the first main factor, consumers from Poland and Lithuania experienced different service problems. They were associated with unhygienic behavior of waiters, like touching tableware or glassware, which could have resulted in secondary pollution. Other factors were classified in a different order. For example, Lithuanians clearly appreciated a restaurant's services for its speed of work and lack of mistakes while, for Poles, the hygiene of the table and plates and the size of meal portions were more important.

\section{Practical Implications}

This publication provides new actionable conclusions for both the restaurant managers and consumers. Managers can strengthen their knowledge of restaurant selection decisions and problems of meal quality and restaurant service. On the other hand, consumers can increase their knowledge about sustainable practices related to the environmental aspects of restaurant operations.

Generally speaking, restaurateurs should monitor the satisfaction of their customers and recognize the cause for the complaints, in order to subsequently find solutions to the problems indicated. Proper complaint handling processes may not only increase customer satisfaction and stimulate revisit [25], but also influence the food quality and consequently positively impact the greater public health.

\section{Conclusions}

The use of multidimensional calculations, i.e., cluster analysis and principal component analysis (PCA), allowed a comprehensive assessment of consumer opinions on restaurants in terms of meal quality and service as well as sustainable practices. Polish and Lithuanian consumers used catering services with varying frequencies. In selecting the restaurant, they relied on different factors influencing their decision. However, the common feature was the quality of meals, which in Lithuania was compared only with the price of meals, and in Poland with many other factors.

In the context of restaurant's sustainable practices, it has been revealed that the surveyed consumers only partially fit into contemporary environment-friendly, locally-sourced, and organic food consumption trends. In both countries, consumers appreciate the use of reusable cutlery and crockery, and local and seasonal ingredients, while they did not pay attention to sustainable restaurant practices, such as the use of alternative sources of protein, environmentally friendly forms of energy, reducing waste, and minimization of food losses.

The surveyed restaurant consumers stated both the poor quality of meals and improper consumer service practices. The main factor in Poland affecting the negative opinion of consumers on the quality of meals served in restaurants was strange taste while, in Lithuania, it was too low of a temperature of hot meals. However, in the context of restaurant service complaints, similarities were found regarding the main factor, such as unhygienic restaurant service practices involving touching the tableware and the edges of the glasses with bare hands. The obtained results indicate the places for the necessary improvement of meal quality, guest service, and strengthening the consumers' awareness of the effects of food production in restaurants on environmental changes.

Restaurateurs should monitor the satisfaction of their customers and recognize the changing needs and habits of consumers, as well as recognize the quality of service and current causes of complaints.

Author Contributions: J.T.-conceptualization, methodology, validation, investigation, writing—original draft preparation, supervision, writing - review, and editing. E.C.-S.-conceptualization, methodology, validation, investigation, writing — original draft preparation, supervision, writing — review and editing. J.K.- investigation. N.V.-investigation. All authors have read and agreed to the published version of the manuscript.

Funding: Research financed by Polish Ministry of Science and Higher Education within funds of Institute of Human Nutrition Sciences, Warsaw University of Life Sciences (WULS) for scientific research.

Conflicts of Interest: The authors declare no conflict of interest. 


\section{Appendix A}

Table A1. Questionnaire structure.

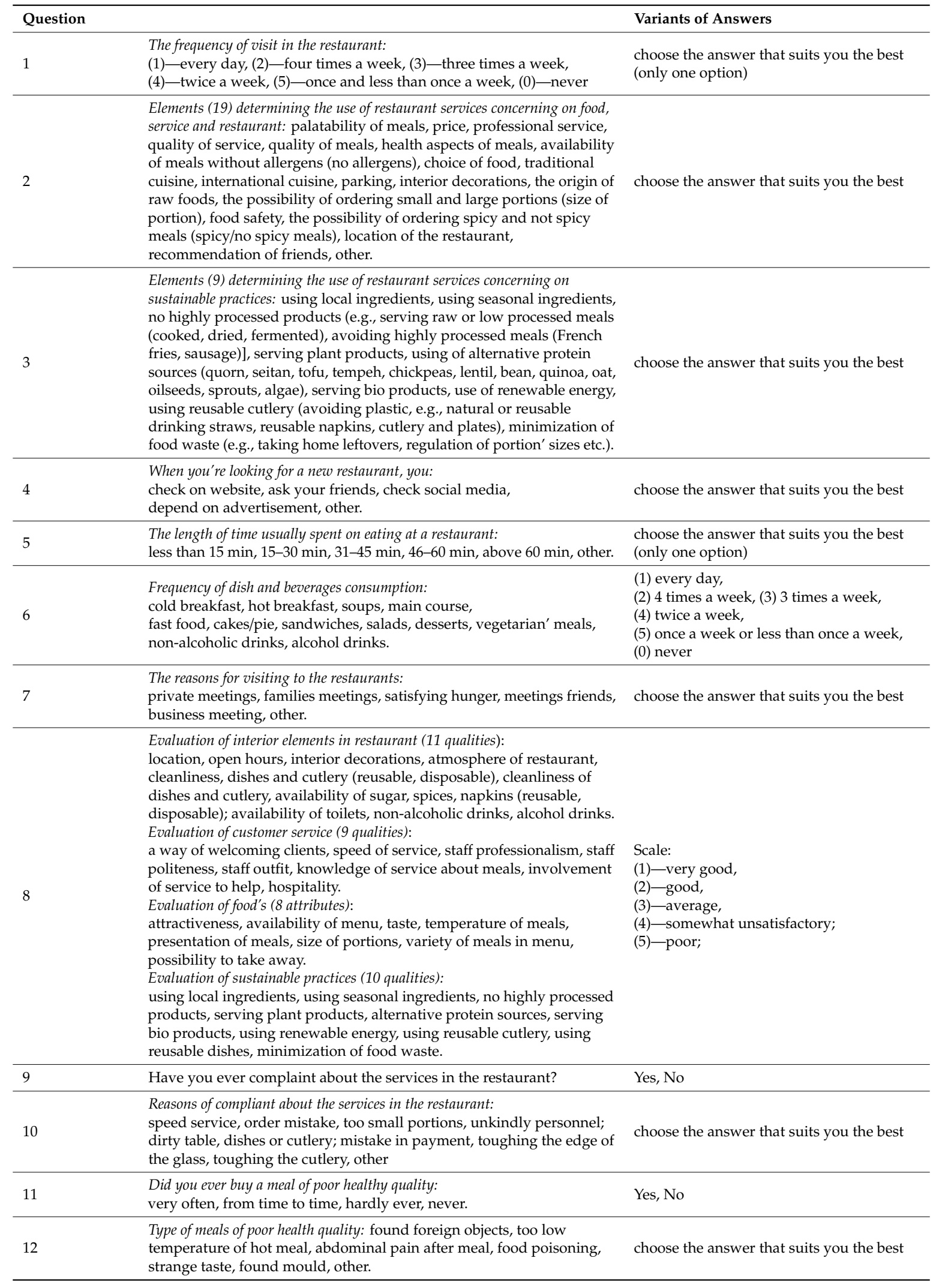


Table A1. Cont.

\begin{tabular}{lll}
\hline Question & & Variants of Answers \\
& Sociodemographic data: & \\
& Gender: women, men; \\
& Age: $18-25$ years old, 26-50 years old; \\
& Education: secondary school, higher education (university); & \\
& Marital status: single, married; & \\
& Dwelling place: village, city up to 100,000 inhabitants, city & choose the answer that suits you the best \\
& 100,000-500,000 inhabitants, city over 500,000 inhabitants; & (only one to each data) \\
& Inhabitation: alone, couple, partly alone-partly with family, & \\
& with family/friends; & \\
& Occupation: employed, unemployed; & \\
& Evaluation of financial status (in own opinion): very good, good, not & \\
& good not bad, bad, very bad. &
\end{tabular}

\section{References}

1. Kowalczuk, I.; Czarniecka-Skubina, E. Eating out in Poland: Status, perspectives and trends-A review. Sci. J. Univ. Szczec. Serv. Manag. 2015, 2, 75-83. [CrossRef]

2. Gheribi, E. Factors affecting the development of catering enterprises in Poland. Econ. Probl. Tour. 2015, 31, 207-220. [CrossRef]

3. Müller, C.; Stucki, M.; Zehnder, P.; Ebker, J.; Wohlleben, M.; Baumer, B. The "Menu Sustainability Index". Assessment of the environmental and health impact of foods offered in commercial catering. Ernahr. Umsch. 2016, 63, 198-205. [CrossRef]

4. Renner, B.; Sproesser, G.; Strohbach, S.; Schupp, H.T. Why we eat what we eat. The Eating Motivation Survey (TEMS). Appetite 2012, 59, 117-128. [CrossRef] [PubMed]

5. Bălășescu, S. Bio agricultural product market in Romania and Europe. Bull. Transilv. Univ. Brasov 2016, 9, $265-272$.

6. Hoek, A.; Pearson, D.; James, S.; Lawrence, M.; Friel, S. Shrinking the foodprint: A qualitative study into consumer perceptions, experiences and attitudes towards healthy and environmentally friendly food behaviours. Appetite 2017, 108, 117-131. [CrossRef]

7. European Parliament and Council. Regulation (EU) No 1169/2011 of the European Parliament and of the Council of 25 October 2011 on the Provision of Food Information to Consumers, Amending Regulations (EC) No 1924/2006 and (EC) No 1925/2006 of the European Parliament and of the Council, and Repealing Commission Directive 87/250/EEC, Council Directive 90/496/EEC, Commission Directive 1999/10/EC, Directive 2000/13/EC of the European Parliament and of the Council, Commission Directives 2002/67/EC and 2008/5/EC and Commission Regulation (EC) No 608/. Off. J. Eur. Union 2011, 18-63. Available online: http: //data.europa.eu/eli/reg/2011/1169/oj (accessed on 20 November 2019).

8. McIntosh, J.; Flanagan, A.; Madden, N.; Mulcahy, M.; Dargan, L.; Walker, M.; Burns, D.T. Awareness of coeliac disease and the gluten status of 'gluten-free' food obtained on request in catering outlets in Ireland. Int. J. Food Sci. Technol. 2011, 46, 1569-1574. [CrossRef]

9. Hattersley, S.; King, R. Catering-How to Keep Allergic Consumers Happy and Safe. Chapter 10. Risk Manag. Food Allergy 2014, 189-200. [CrossRef]

10. Zlatevska, N.; Dubelaar, C.; Holden, S.S. Sizing up the effect of portion size on consumption: A meta-analytic review. J. Mark. 2014, 78, 140-154. [CrossRef]

11. Hollands, G.J.; Shemilt, I.; Marteau, T.M.; Jebb, S.A.; Lewis, H.B.; Wei, Y.; Higgins, J.P.T.; Ogilvie, D. Portion, package or tableware size for changing selection and consumption of food, alcohol and tobacco. Cochrane Database Syst. Rev. 2015, 9, Cd011045. [CrossRef] [PubMed]

12. Marteau, T.M.; Hollands, G.J.; Shemilt, I.; Jebb, S.A. Downsizing: Policy options to reduce portion sizes to help tackle obesity. Br. Med. J. 2015, 351, h5863. [CrossRef] [PubMed]

13. Jung, J.M.; Sydnor, S.; Lee, S.K.; Almanza, B. A conflict of choice: How consumers choose where to go for dinner. Int. J. Hosp. Manag. 2015, 45, 88-98. [CrossRef]

14. Filimonau, V.; Krivcova, M. Restaurant menu design and more responsible consumer food choice: An exploratory study of managerial perceptions. J. Clean. Prod. 2017, 143, 516-527. [CrossRef]

15. Yu, Y.S.; Luo, M.; Zhu, D.H. The effect of quality attributes on visiting consumers' patronage intentions of green restaurants. Sustainability 2018, 10, 1187. [CrossRef] 
16. Edwards, J.S.A. The foodservice industry: Eating out is more than just a meal. Food Qual. Prefer. 2013, 27, 223-229. [CrossRef]

17. Baldwin, C.; Wilberforce, N.; Kapur, A. Restaurant and food service life cycle assessment and development of a sustainability standard. Int. J. Life Cycle Assess. 2011, 16, 40-49. [CrossRef]

18. Haghighi, M.; Dorosti, A.; Rahnama, A.; Hoseinpour, A. Evaluation of factors affecting customer loyalty in the restaurant industry. Afr. J. Bus. Manag. 2012, 6, 5039-5046.

19. Walter, U.; Edvardsson, B. The physical environment as a driver of customers' service experiences at restaurants. Int. J. Qual. Serv. Sci. 2012, 4, 104-119. [CrossRef]

20. Gneezy, A.; Gneezy, U.; Lauga, D.O. A reference-dependent model of the price-quality heuristic. J. Mark. Res. 2014, 51, 153-164. [CrossRef]

21. Pecotić, M.; Bazdan, V.; Samardžija, J. Interior Design in Restaurants as a Factor Influencing Customer Satisfaction. RIThink 2014, 4, 10-14.

22. Andersen, B.V.; Hyldig, G. Consumers' view on determinants to food satisfaction. A qualitative Approach. Appetite 2015, 95, 9-16. [CrossRef] [PubMed]

23. Pilelienè, L.; Almeida, N.; Grigaliunaite, V. Customer satisfaction in catering industry: Contrasts between Lithuania and Portugal. Tour. Manag. Stud. 2016, 12, 53-59. [CrossRef]

24. Almohaimmeed, B.M.A. Restaurant Quality and Customer Satisfaction. Int. Rev. Manag. Mark. 2017, 7, 42-49.

25. Konuk Faruk, A. The influence of perceived food quality, price fairness, perceived value and satisfaction on customers' revisit and word-of-mouth intentions towards organic food restaurants. J. Retail. Consum. Serv. 2019, 50, 103-110. [CrossRef]

26. Liu, Y.; Song, Y.; Sun, J.; Sun, C.; Liu, C.; Chen, X. Understanding the relationship between food experiential quality and customer dining satisfaction: A perspective on negative bias. Int. J. Hosp. Manag. 2020. [CrossRef]

27. Harrington, R.J.; Ottenbacher, M.C.; Kendall, K.W. Fine-dining restaurant selection: Direct and moderating effects of customer attributes. J. Foodserv. Bus. Res. 2011, 14, 272-289. [CrossRef]

28. Namkung, Y.; Jang, S. Does food quality really matter in restaurants? Its impact on customer satisfaction and behavioral intentions. J. Hosp. Tour. Res. 2007, 31, 387-410. [CrossRef]

29. Ha, J.; Jang, S. The effects of dining atmospherics on behavioral intentions through quality perception. J. Serv. Mark. 2012, 26, 204-215. [CrossRef]

30. Ryu, K.; Han, H. Influence of the quality of food, service, and physical environment on customer satisfaction and behavioral intention in quick-casual restaurants: Moderating role of perceived price. J. Hosp. Tour. Res. 2010, 34, 310-329. [CrossRef]

31. Namkung, Y.; Jang, S. Are highly satisfied restaurant customers really different? A quality perception perspective. Int. J. Contemp. Hosp. Manag. 2008, 20, 142-155. [CrossRef]

32. Ryu, K.; Jang, S. The effect of environmental perceptions on behavioral intentions through emotions: The case of upscale restaurants. J. Hosp. Tour. Res. 2007, 31, 56-72. [CrossRef]

33. Ha, J.; Jang, S. Effects of service quality and food quality: The moderating role of atmospherics in and ethnic restaurant segment. Int. J. Hosp. Manag. 2010, 29, 520-529. [CrossRef]

34. Liu, J.; Petit, E.; Brit, A.-C.; Giboreau, A. The impact of tablecloth on consumers' food perception in real-life eating situation. Food Qual. Prefer. 2019, 71, 168-171. [CrossRef]

35. Biswas, D.; Szocs, C.; Chacko, R.; Wansink, B. Shining light on atmospherics: How ambient light influences food choices. J. Mark. Res. 2017, 54, 111-123. [CrossRef]

36. Hwang, K.; Lee, B. Pride, mindfulness, public self-awareness, affective satisfaction and customer citizenship behaviour among green restaurant customers. Int. J. Hosp. Manag. 2019, 83, 169-179. [CrossRef]

37. Gössling, S.; Garrod, B.; Aall, C.; Hille, J.; Peeters, P. Food management in tourism: Reducing tourism's carbon 'foodprint'. Tour. Manag. 2011, 32, 534-543. [CrossRef]

38. Hu, M.L.; Horng, J.S.; Teng, C.C.; Chou, S.F. A criteria model of restaurant Energy conservation and carbon reduction in Taiwan. J. Sustain. Tour. 2013, 21, 765-779. [CrossRef]

39. Kerstens, S.M.; Priyanka, A.; Van Dijk, K.C.; De Ruijter, F.J.; Leusbrock, I.; Zeeman, G. Potential demand for recoverable resources from Indonesian wastewater and solid waste. Resour. Conserv. Recycl. 2016, 110, 16-29. [CrossRef]

40. Martin-Rios, C.; Demen-Meier, C.; Gössling, S.; Cornuz, C. Food waste management innovations in the foodservice industry. Waste Manag. 2018, 79, 196-206. [CrossRef] 
41. Chou, C.-J.; Chen, C.-S.; Wang, Y.-Y. Green practices in the restaurant industry from an innovation adoption perspective: Evidence from Taiwan. Int. J. Hosp. Manag. 2012, 31, 703-711. [CrossRef]

42. Egilmez, G.; Kucukvar, M.; Tatari, O.; Bhutta, M.K.S. Supply chain sustainability assessment of the U.S. food manufacturing sectors: A life cycle-based frontier approach. Resour. Conserv. Recycl. 2014, 82, 8-20. [CrossRef]

43. DiPietro, R.; Cao, Y.; Partlow, C. Green practices in upscale foodservice operations: Customer perceptions and purchase intentions. Int. J. Contemp. Hosp. Manag. 2013, 25, 779-796. [CrossRef]

44. Namkung, Y.; Jang, S. Are consumers willing to pay more green practices at restaurants? J. Hosp. Tour. Res. 2014, 41, 329-356. [CrossRef]

45. Filimonau, V.; Lemmer, C.; Marshall, D.; Bejjani, G. Restaurant menu re-design as a facilitator of more responsible consumer choice; An exploratory and preliminary study. J. Hosp. Tour. Manag. 2017, 33, 73-81. [CrossRef]

46. Papaoikonomou, E.; Ryan, G.; Ginieis, M. Towards a holistic approach of the attitude behavior gap in ethical consumer behaviors: Empirical evidence from Spain. Int. Adv. Econ. Res. 2011, 17,77-88. [CrossRef]

47. Stroebele-Benschop, N.; Depa, J.; de Castro, J.M. Environmental strategies to promote food intake in older adults: A narrative review. J. Nutr. Gerontol. Geriatr. 2016, 35, 95-112. [CrossRef]

48. Băltescu, C.A. The attractiveness of green restaurants among the youth. Bull. Transilv. Univ. Brasov Ser. V Econ. Sci. 2017, 10, 79-84.

49. Kallbekken, S.; Sælen, H. Nudging' hotel guests to reduce food waste as a win- win environmental measure. Econ. Lett. 2013, 119, 325-327. [CrossRef]

50. Nicholls, S.; Kang, S. Green initiatives in the lodging sector: Are properties putting their principles into practice? Int. J. Hosp. Manag. 2012, 31, 609-611. [CrossRef]

51. Jang, Y.J.; Zheng, T.; Bosselman, R.H. Top managers' environmental values, leadership, and stakeholder engagement in promoting environmental sustainability in the restaurant industry. Int. J. Hosp. Manag. 2017, 63, 101-111. [CrossRef]

52. Garay, L.; Font, X. Doing good to do well? Corporate social responsibility reasons, practices, and impacts in small and medium accommodation enterprises. Int. J. Hosp. Manag. 2012, 31, 329-337. [CrossRef]

53. Park, J.; Kim, H.J. Environmental proactivity of hotel operations: Antecedents and the moderating effect of ownership type. Int. J. Hosp. Manag. 2014, 37, 1-10. [CrossRef]

54. Perramon, J.; del Mar Alonso-Almeida, M.; Llach, J.; Bagur-Femenías, L. Green practices in restaurants: Impact on firm performance. Oper. Manag. Res. 2014, 7, 2-12. [CrossRef]

55. Kasim, A.; Ismail, A. Environmentally friendly practices among restaurants: Drivers and barriers to change. J. Sustain. Tour. 2012, 20, 551-570. [CrossRef]

56. Namkung, Y.; Jang, S. Effects of restaurant green practices on brand equity formation: Do green practices really matter? Int. J. Hosp. Manag. 2013, 33, 85-95. [CrossRef]

57. Iaquinto, A. Sustainable Practices among Independently Owned Restaurants in Japan. J. Foodserv. Bus. Res. 2014, 17, 147-159. [CrossRef]

58. Ma, J.; Ghiselli, R. Measuring, monitoring, and managing the green practices in mid-sized restaurants in China. J. Foodserv. Bus. Res. 2016, 19, 64-76. [CrossRef]

59. Raab, C.; Baloglu, S.; Chen, Y.-S. Restaurant Managers' Adoption of Sustainable Practices: An Application of Institutional Theory and Theory of Planned Behavior. J. Foodserv. Bus. Res. 2018, 21, 154-171. [CrossRef]

60. Schubert, F.; Kandampully, J.; Solnet, D.; Kralj, A. Exploring Consumer Perceptions of Green Restaurants in the US. Tour. Hosp. Res. 2010, 10, 286-300. [CrossRef]

61. DiPietro, R.B.; Gregory, S.; Jackson, A. Going Green in Quick-Service Restaurants: Customer Perceptions and Intentions. Int. J. Hosp. Tour. Adm. 2013, 14, 139-156. [CrossRef]

62. Dewald, B.; Bruin, B.J.; Jang, Y.J. US consumer attitudes towards "green" restaurants. Anatolia 2014, 25, 171-180. [CrossRef]

63. Ju, S.; Chang, H. Consumer perceptions on sustainable practices implemented in foodservice organizations in Korea. Nutr. Res. Pract. 2016, 10, 108-114. [CrossRef] [PubMed]

64. Sarmiento, C.V.; El Hanandeh, A. Customers' perceptions and expectations of environmentally sustainable restaurant and the development of green index: The case of the Gold Coast, Australia. Sustain. Prod. Consum. 2018, 15, 16-24. [CrossRef]

65. Central Statistical Office-CSO. Rocznik Statystyczny Rzeczpospolitej Polskiej (Statistical Yearbook of the Republic of Poland); GUS: Warsaw, Poland, 2018. 
66. Maisto Produktu Aprašas. Food Description. 2019. Available online: https://archyvas.produktukainos.lt/ ?mid=112 (accessed on 5 September 2019).

67. Kanopaite, V. The Impact of Experimental Marketing Use on Customer Perceived Value and Satisfaction in Lithuanian Restaurants. Master's Thesis, ISM University of Management and Economics, Kaunas, Lithuania, 2015. [CrossRef]

68. Van Iwaarden, J.; van der Wiele, T.; Ball, L.; Millen, R. Applying SERVQUAL to web sites: An exploratory study. Int. J. Qual. Reliab. Manag. 2003, 20,919-935. [CrossRef]

69. Parasuraman, A.; Zeithaml, V.A.; Berry, L.L. Refinement and reassessment of the SERVQUAL scale. J. Retail. 1991, 67, 420-450.

70. Czarniecka-Skubina, E. The quality of catering services from the dietary, technological and hygienic aspects. Żywność. Nauka. Technol. Jakość 2006, 1, 25-34, (In Polish, abstract in English).

71. Czarniecka-Skubina, E.; Szczepańska, A. The quality of catering services in school's canteens in consumers' opinion. In Wybrane Aspekty Zarzadzania Jakościa; Salerno-Kochan, M., Ed.; Economic University in Cracov: Cracov, Poland, 2012; pp. 95-99. ISBN 978-83-929209-3-9. (In Polish, abstract in English).

72. Czarniecka-Skubina, E. Customer satisfaction surveys in assessing clients' opinion on the quality of the catering services on example of a restaurant. In Selected Problems in the Field of Nutrition and Food Production; kołożyn-Krajewska, D., Ed.; Hospitality Management and Tourism in Czestochowa: Czestochowa, Poland, 2013; pp. 8-21. ISBN 978-83-933915-3-0.

73. Czarniecka-Skubina, E.; Trafiałek, J.; Wiatrowski, M.; Głuchowski, A. An Evaluation of the Hygiene Practices of European Street Food Vendors and a Preliminary Estimation of Food Safety for Consumers, Conducted in Paris. J. Food Prot. 2018, 81, 1614-1621. [CrossRef]

74. Mróz, B. Consumerism vs. sustainability: The emergence of new consumer trends in Poland. Int. J. Econ. Policy Emerg. Econ. 2010, 3, 1-15. [CrossRef]

75. Alraub, A.S.A.; Alsaleem, A.S.M.; Daoud, A.A. Service quality and its impact on customer satisfaction tourist restaurants (a field study on the tourist restaurants/amman). Interdiscip. J. Contemp. Res. Bus. 2012, 4, 364-368.

76. Malhotra, N.K.; Nunan, D.; Birks, D.F. Marketing Research: An Applied Approach, 5th ed.; Pearson: London, UK, 2017.

77. Hennig, C.; Meila, M.; Murtagh, F.; Rocci, R. Handbook of Cluster Analysis; CRC Press: Boca Raton, FL, USA, 2015.

78. Trafiałek, J.; Kolanowski, W. Implementation and functioning of HACCP principles in certified and non-certified food business: A preliminary study. Br. Food J. 2017, 119, 710-728. [CrossRef]

79. Mazzocchi, M. Factor Analysis and Principal Component Analysis. In Statistics for Marketing and Consumer Research; SAGE: Thousand Oaks, CA, USA, 2011. [CrossRef]

80. Kowalczuk, I. Consumer Behavior on the Foodservice Market-Marketing Aspect; SGGW: Warsaw, Poland, 2012. (In Polish)

81. Czarniecka-Skubina, E.; Górska-Warsewicz, H.; Laskowski, W.; Jeznach, M. Consumer choices and service quality in the university canteens in Warsaw, Poland. Int. J. Environ. Res. Public Health 2019, 16, 3699. [CrossRef] [PubMed]

82. Kolanowski, W.; Trafiałek, J.; Drosinos, E.H.; Tzamalis, P. Polish and Greek young adults' experience of low quality meals when eating out. Food Control 2020, 109, 106901. [CrossRef]

83. Tu, Y.-T.; Lin, S.Y.; Chang, Y.Y. Relationships among Service Quality, Customer Satisfaction and Customer Loyalty in Chain Restaurant. Inf. Manag. Bus. Rev. 2011, 3, 273-282. [CrossRef]

84. Wang, C.H.; Chen, S.C. The relationship of full-service restaurant attributes, evaluative factors and behavioral intention. Int. J. Organ. Innov. 2012, 5, 248-262.

85. Jeong, E.; Jang, S. Restaurant experiences triggering positive electronic word-of mouth (eWOM) motivations. Int. J. Hosp. Manag. 2011, 30, 356-366. [CrossRef]

86. Al-Tit, A.A. The Effect of Service and Food Quality on Customer Satisfaction and Hence Customer Retention. Asian Soc. Sci. 2015, 11, 129-139. [CrossRef]

87. Marinelli, N.; Simeone, M.; Scarpato, D. Does quality really matter? Variables that drive postmodern consumer choices. Nutr. Food Sci. 2015, 45, 255-269. [CrossRef]

88. Yucedag, C.; Gurkan, K.L.; Mehmet, C. Identifying and assessing environmental awareness of hotel and restaurant employees' attitudes in the Amasra District of Bartin. Environ. Monit. Assess. 2018, 190, 60. [CrossRef]

89. Majumder, A.K. Assessments of environmental awareness among the some selective university students of Bangladesh. Am. J. Educ. Inf. Technol. 2017, 1, 38-42. [CrossRef] 
90. Kearney, J. Food Consumption Trends and Drivers. Philos. Trans. R. Soc. B Biol. Sci. 2010, 365, $2793-2807$. [CrossRef] [PubMed]

91. Springmann, M.; Clark, M.; Mason-D'Croz, D.; Wiebe, K.; Bodirsky, B.L.; Lassaletta, L.; de Vries, W.; Vermeulen, S.J.; Herrero, M.; Carlson, K.M.; et al. Options for keeping the food system within environmental limits. Nature 2018, 562, 519-525. [CrossRef] [PubMed]

92. Lombardini, C.; Lankoski, L. Forced Choice Restriction in Promoting Sustainable Food Consumption: Intended and Unintended Effects of the Mandatory Vegetarian Day in Helsinki Schools. J. Consum. Policy 2013, 36, 159-178. [CrossRef]

93. Reinders, M.J.; Huitink, M.; Dijkstra, S.C.; Maaskant, A.J.; Heijnen, J. Menu-engineering in restaurants-Adapting portion sizes on plates to enhance vegetable consumption: A real-life experiment. Int. J. Behav. Nutr. Phys. Act. 2017, 14, 41. [CrossRef]

94. Hamerman, E.J.; Rudell, F.; Martins, C.M. Factors that predict taking restaurant leftovers: Strategies for reducing food waste. J. Consum. Behav. 2018, 17, 94-104. [CrossRef]

95. Stancu, V.; Haugaard, P.; Lähteenmäki, L. Determinants of consumer food waste behavior: Two routes to food waste. Appetite 2016, 96, 7-17. [CrossRef]

96. Alonso-Almeida, M.M.; Rocafort, A.; Borrajo, F. Shedding Light on Eco-Innovation in Tourism: A Critical Analysis. Sustainability 2016, 8, 1262. [CrossRef]

97. Teng, C.C.; Chang, J.H. Effects of temporal distance and related strategies on enhancing customer participation intention for hotel eco-friendly programs. Int. J. Hosp. Manag. 2014, 40, 92-99. [CrossRef]

98. Alonso-Almeida, M.M. Water and waste management in the Moroccan tourism industry: The case of three women entrepreneurs. Women's Stud. Int. Forum 2012, 35, 343-353. [CrossRef]

99. Bastic, M.; Gojic, S. Measurement scale for eco-component of hotel service quality. Int. J. Hosp. Manag. 2012, 31, 1012-1020. [CrossRef]

100. Horng, J.S.; Chou, S.F.; Liu, C.H.; Tsai, C.Y. Creativity, aesthetics and eco-friendliness: A physical dining environment design synthetic assessment model of innovative restaurants. Tour. Manag. 2013, 36, 15-25. [CrossRef]

101. Kwok, L.; Huang, Y.K.; Hu, L. Green attributes of restaurants: What really matters to consumers? Int. J. Hosp. Manag. 2018, 55, 107-117. [CrossRef]

102. Razza, F.; Fieschi, M.; Innocenti, F.D.; Bastioli, C. Compostable cutlery and waste management: An LCA approach. Waste Manag. 2009, 29, 1424-1433. [CrossRef] [PubMed]

103. Pielak, M.; Trafiałek, J.; Czarniecka-Skubina, E. Evaluation of the diversity of gastronomic offer in one selected tourist place in Thailand. Żywność. NaukaTechnol. Jakość 2018, 25, 152-163. [CrossRef]

104. Worsfold, D. Eating out: Consumer perceptions of food safety. Int. J. Environ. Health Res. 2006, 16, $219-229$. [CrossRef]

105. Lemos, G.J.; Garcia, M.V.; de Oliveira Mello, R.; Copetti, M.V. Consumers complaints about moldy foods in a Brazilian website. Food Control 2018, 92, 380-385. [CrossRef]

106. Gautam, A.M.; Caetano, N. Study, design and analysis of sustainable alternatives to plastic takeaway cutlery and crockery. Energy Procedia 2017, 136, 507-512. [CrossRef]

107. Liu, R.; Grunert, K.G. Satisfaction with food-related life and beliefs about food health, safety, freshness and taste among the elderly in China: A segmentation analysis. Food Qual. Prefer. 2020, 79, 103775. [CrossRef]

108. Kim, Y.S.; Hertzman, J.; Hwang, J.J. College students and quick-service restaurants: How students perceive restaurant food and services. J. Foodserv. Bus. Res. 2010, 13, 346-359. [CrossRef]

109. Bai, L.; Wang, M.; Yang, Y.; Gong, S. Food safety in restaurants: The consumer perspective. Int. J. Hosp. Manag. 2019, 77, 139-146. [CrossRef]

110. Aguiar, R.S.; Esmerino, E.A.; Rocha, R.S.; Pimentel, T.S.; Alvarenga, V.O.; Freitas, M.Q.; Silva, M.C.; San'tAna, A.S.; Silva, A.C.O.; Cruz, A.G. Physical hazards in dairy products: Incidence in a consumer complaint website in Brazil. Food Control 2018, 86, 66-70. [CrossRef]

111. Djekic, I.; Jankovic, D.; Rajkovic, A. Analysis of foreign bodies present in European food using data from Rapid Alert System for Food and Fed (RASFF). Food Control 2017, 79, 143-149. [CrossRef]

112. Trafialek, J.; Kaczmarek, S.; Kolanowski, W. The risk analysis of metallic foreign bodies in food products. J. Food Qual. 2016, 39, 398-407. [CrossRef]

113. Jahandideh, B.; Golmohammadi, A.; Meng, F.; O’Gorman, K.D.; Taheri, B. Cross-cultural comparison of Chinese and Arab consumer complaint behavior in the hotel context. Int. J. Hosp. Manag. 2014, 41, 67-76. [CrossRef] 
114. Wu, H.C. An empirical study of the effects of service quality, perceived value, corporate image, and customer satisfaction on behavioral intentions in the Taiwan quick service restaurant industry. J. Qual. Assur. Hosp. Tour. 2013, 14, 364-390. [CrossRef]

115. Lupo, T.; Bellomo, E. DINESERV along with fuzzy hierarchical TOPSIS to support the best practices observation and service quality improvement in the restaurant context. Comput. Ind. Eng. 2019, 137, 106046. [CrossRef]

(c)

(C) 2019 by the authors. Licensee MDPI, Basel, Switzerland. This article is an open access article distributed under the terms and conditions of the Creative Commons Attribution (CC BY) license (http://creativecommons.org/licenses/by/4.0/). 